7. Kleinman, L. J., Petering, H. G., and Sutherland, J. M.: Blood carbonic anhydrase activity and zinc concentration in infants with respiratory distress syndrome. N. Eng. J. Med., 277: 1157 (1967).

8. Kleinman, L. J.. Sell, J. E., and Petering, H. G.: Carbonic anhydrase isoenzymes in infants with respiratory distress syndrome. Amer. J. Dis. Child. 124: 696 (1972).

9. Kotas, R. V., and Avery, M. E.: Accelerated appearance of pulmonary surfactant in the fetal rabbit. J. Appl. Physiol., 30: 358 (1971).

10. Logan, R. W., Crooks, S. M., Hutchison, J. H., and Kerr, M. M.: Blood carbonic anhydrase activity in the newborn. Arch. Dis. Childhood, 48: 256 (1973)

11. Motoyama, E. K., Orzalesi, M. M., Kikkawa. Y., Kaibara, M., Wu, B., Zigos, C. J., and Cook, C. D.: Effect of cortisol on the maturation of fetal rabbit lungs. Pediatrics, 38: 547 (1971)

12. Murphy, B. E. P.: Evidence of cortisol deficiency at birth in infants with the respiratory distress syndrome. J. Clin. Endocrinol., 38: 158 (1974).

13. Narumi, S., and Miyamoto, E.: Activation and phosphorylation of carbonic anhydrase by adenosine $3^{\prime} 5^{\prime}$-monophosphate-dependent protein kinases. Biochem. Biophys. Acta, 350: 215 (1974)

14. Roughton, F.J.W., and Booth, V. H.: The effect of substrate concentration, pH, and other factors upon the activity of carbon anhydrase. Biochem. J., 40:319 (1946).

Copyright (C) 1976 International Pediatric Research Foundation, Inc.
15. Russell, B. J., Nugent, L., and Chernick, V.: Effects of steroids on the enzymatic pathways of lecithin production in fetal rabbits. Biol. Neonate, 24: 306 (1974).

16. Sell, J. E., and Petering, H. G.: Carbonic anhydrases from human neonatal erythrocytes. J. Lab. Clin. Med., 84: 369 (1974).

17. Stadie, W. C.: A method for the determination of methemoglobin in blood. J. Biol. Chem., 41: 237 (1920).

18. Stevenson, S. S.: Carbonic anhydrase in newborn infants. J. Clin. Invest., 22: 403 (1943).

19. Suzuki, S., Ogawa, E., and Shibata, K.: Experimental studies on the carbonic anhydrase activity. IX. The mode of action of adrenocortical steroids, especially aldosterone on the carbonic anhydrase in mice and rats. Endocrinol. Jap., 14: 107 (1967).

20. Wang, N. S., Kotas, R. V., Avery, M. E., and Thurlbeck, W. M.: Accelerated appearance of osmiophitic bodies in fetal lungs following steroid injection. $J$. Appl. Physiol., 30: 362 (1971).

21. We are grateful to Mrs. P. Trudel for typing the manuscript.

22. This research was supported by the Medical Research Council of Canada and the Children's Hospital of Winnipeg Research Foundation, Inc.

23. Requests for reprints should be addressed to: V. Chernick, M.D., Children's Centre, 685 Bannatyne Ave., Winnepeg, Manitoba R3E OW1 (Canada).

24. Accepted for publication March 17, 1976.
Bilirubin promethazine induction $\mathrm{Rh}$ erythroblastosis liver

\title{
Spectrophotometric Characteristics of Bilirubin
}

\author{
KWANG-SUN LEE AND LAWRENCE M. GARTNER ${ }^{(43)}$ \\ Department of Pediatrics, Rose F. Kennedy Center and Liver Research Center, Albert Einstein College of Medicine, \\ Bronx, New York
}

\section{Extract}

Spectrophotometric characteristics of bilirubin at low concentrations $(0.005-2.500 \mathrm{mg} / 100 \mathrm{ml})$ have been studied under various physical conditions in order to gain a better understanding of the state of bilirubin when preparing "solutions" for laboratory use. Standing, minimal shaking, or stirring of the bilirubin preparations at $\mathrm{pH} 7.4$ progressively reduced and altered the maximal spectral absorption of bilirubin $(440 \mathrm{~nm})$ in aqueous buffered media. The shift to $415-420 \mathrm{~nm}$ is attributed to oxidation of the pigment whereas shoulder formation is attributed to the formation of large size particles (flocculants). In the presence of antioxidants (L-ascorbic acid and nitrogen gas) and EDTA the maximal absorption peak remained at $440 \mathrm{~nm}$ but decreased in magnitude concomitant with development of a progressively increasing shoulder at $\mathbf{4 8 0}-560$ $\mathrm{nm}$. In the absence of antioxidants and EDT A maximal absorption shifted to $415-420 \mathrm{~nm}$ and the magnitude of $480-560 \mathrm{~nm}$ shoulder formation was less. At the higher concentrations of bilirubin and with reduction in $\mathrm{pH}$ of the buffer in the absence of antioxidants, the shift to lower wave lengths was reduced and $480-560 \mathrm{~nm}$ shoulder formation was increased. In the absence of antioxidants and EDTA at the lower concentrations of bilirubin and in more alkaline media, the reduction at $440 \mathrm{~nm}$ and the shift of maximal absorption to the shorter wave lengths was enhanced. At $\mathrm{pH} \mathrm{12,} \mathrm{stirring} \mathrm{of} \mathrm{anti-}$ oxidant-EDTA-containing solutions of bilirubin resulted in neither a shift of maximal absorption to the shorter wave lengths nor the formation of $480-560 \mathrm{~nm}$ shoulder. The formation of $480-560 \mathrm{~nm}$ shoulder was accompanied by the visual appearance of turbidity. The formation of flocculants when a "solution" is agitated indicates that significant portions of the pigment were in fact, not in solution and must have existed previously as a finely dispersed colloidal sol or supersaturated solution which progressed to a colloidal sol.

Spectral curves of bilirubin, therefore, may represent a composite resulting from four physical states of bilirubin: $(1)$ bilirubin truly in solution with the spectral peak at $440 \mathrm{~nm}$; (2) bilirubin in the fine colloidal dispersion with spectral characteristics similar to those of bilirubin in solution; (3) bilirubin flocculant giving $480-560 \mathrm{~nm}$ shoulder; and (4) oxidation products of bilirubin with the spectral peaks lower than $440 \mathrm{~nm}$.

Increasing the $\mathrm{pH}$ of the aqueous media containing bilirubin $(0.05$ $\mathrm{mg} / 100 \mathrm{ml}$ ) from 7.4 to 12.0 increased the molar extinction coefficient of bilirubin, $E_{440}^{1 \mathrm{M}, 1 \mathrm{~cm}}$, progressively to a maximum at pH 12 of $6.35 \times 10^{4}$. Very dilute bilirubin preparations $(0.005-$ $0.050 \mathrm{mg} / 100 \mathrm{ml}$ ) in aqueous media, $\mathrm{pH} 7.4$, exhibited spectral evidence of rapid oxidation (more so at higher $\mathrm{pH}$ ), but spectral shoulder formation was still observed after mechanical agitation. Thus, the solubility of bilirubin in $0.1 \mathrm{M}$ phosphate buffer at $\mathrm{pH}$ 7.4 appears to be less than $0.005 \mathrm{mg} / 100 \mathrm{ml}$.

\section{Speculation}

Unbound bilirubin in vivo, at concentrations exceeding albumin binding capacity and its aqueous solubility, is believed to exist either as a colloidal sol (micropolymer) or a flocculant (macropolymer). It is proposed that it is in the colloidal sol form (micropolymer) that bilirubin toxicity to brain, kidney, intestinal mucosa, erythrocyte, and other organs initially develops by a process of colloid to surface interaction. 
Spectrophotometric analysis of bilirubin has been utilized primarily for the determination of bilirubin concentrations $(13,21)$ and for the study of bilirubin-albumin binding in the evaluation of risk for development of kernicterus $(26,37)$. Although the principle has been generally accepted that the height of the molar extinction coefficient of bilirubin in chloroform at $453 \mathrm{~nm}$ is an index of purity of the sample (35), widely varying values have been reported for the maximal visible light absorption wave length and molar absorptivity of bilirubin in aqueous solution $(10,19,37,38)$, human serum albumin solution $(14,19,32,33,39)$, and human sera $(2,19,26,32)$. Similarly, reported values for the "solubility" of bilirubin in aqueous solution have varied widely $(6,7,19,29)$. The reasons for this marked variability in maximal absorption wave length and absorptivity from one laboratory to another remain unclear.

Brodersen and his associates $(3,5,6)$ extensively studied bilirubin colloid formation in both aqueous and albumin solutions. They reported that the true solubility of bilirubin in $0.1 \mathrm{M}$ phosphate buffer at $\mathrm{pH} 7.4$ was about $0.1 \mu \mathrm{M}(0.0058 \mathrm{mg} / 100 \mathrm{ml})$. At concentrations exceeding this value, they reported that bilirubin existed as a colloidal suspension $(3,5,6)$. The formation of large sized bilirubin aggregates resulted in a spectral shoulder at $480-560 \mathrm{~nm}$.

Oxidation of bilirubin by molecular oxygen and light results in spectral alterations characterized by reduction of maximal absorption at $440 \mathrm{~nm}$ and shift of the spectral peak to shorter wave lengths $(8,20,27,28)$.

The instability and uncertain physical states of bilirubin have comprised a serious problem in investigations involving this compound $(37,39)$. Despite the recognition of this problem, there has been no systematic study of the characteristics of bilirubin in relation to the physical environment used in preparing bilirubin for study.

This communcation reports on the spectrophotometric characteristics of bilirubin in aqueous media, crystalline albumin solution, and human sera after mechanical agitation, oxidation, inhibition of oxidation, and alteration of $\mathrm{pH}$. This study also extends the spectral observations of Brodersen and his associates $(3,5,6)$ on the colloidal state of bilirubin and the possible mechanism of bilirubin toxicity in vivo.

\section{METHODS}

Bilirubin used was purchased from Eastman Organic Chemicals and its molar extinction coefficient in chloroform, $E_{453}^{1 M}$. $\mathrm{cm}$, as determined by the method recommended by the Standards Committee of the College of American Pathologists (35), was $5.96 \times$ $10^{4}$. A double beam recording spectrophotometer (Perkin-Elmer) and quartz cuvettes with a $1-\mathrm{cm}$ light path were used for most spectral measurements. For bilirubin concentrations lower than $0.05 \mathrm{mg} / 100 \mathrm{ml}$, cuvettes with $10-\mathrm{cm}$ light path were used.

\section{BILIRUBIN IN PHOSPHATE BUFFER}

Aqueous bilirubin, $0.005-2.500 \mathrm{mg} / 100 \mathrm{ml} 0.1 \mathrm{M}$ phosphate buffer solution (buffer), $\mathrm{pH} 7.4$, was prepared by dissolving $5 \mathrm{mg}$ bilirubin in $10 \mathrm{ml} 0.1 \mathrm{~N} \mathrm{NaOH}$ and adding 1 to $5 \mathrm{ml}$ of the above bilirubin solution to 99 to $95 \mathrm{ml}$ of the buffer at $\mathrm{pH} 7.4$ to which 1 to $5 \mathrm{ml}$ of $0.1 \mathrm{~N} \mathrm{HCl}$ equivalent to the volume of $0.1 \mathrm{~N} \mathrm{NaOH}$ bilirubin solution was added to the buffer before adjustment to final volume of $100 \mathrm{ml}$. Bilirubin in buffer solution was mixed in a beaker with gentle swirling movements or in a graduated cylinder with inversion two to three times, avoiding stirring or shaking unless otherwise stated. If stirring bilirubin in buffer was performed, a magnetic stirrer was utilized at a fixed rate and for a fixed time interval, as stated, in the dark at room temperature ( 24 $\pm 2^{\circ}$ ). Spectrophotometric analysis of bilirubin was performed at wave lengths between 380 and $600 \mathrm{~nm}$ and completed within 10 min after initial dissolution of bilirubin, unless otherwise stated.
Bilirubin-buffer solutions at $\mathrm{pH}$ ranging from 4 to 12 were prepared by adding bilirubin in $0.1 \mathrm{~N} \mathrm{NaOH}$ to the previously adjusted buffer solution to obtain the desired final $\mathrm{pH}$.

\section{AQUEOUS BILIRUBIN WITH L-ASCORBIC ACID AND EDTA}

Aqueous bilirubin $(0.05 \mathrm{mg} / 100 \mathrm{ml})$ containing L-ascorbic acid (Sigma) and EDTA (Sigma) at $\mathrm{pH}$ values ranging from 4 to 12 was prepared similarly by adding bilirubin in $0.1 \mathrm{~N} \mathrm{NaOH}$ to the previously prepared and $\mathrm{pH}$-adjusted buffer solution containing 5 $\mathrm{mM} \mathrm{L}$-ascorbic acid and $2 \mathrm{mM}$ EDTA. The $\mathrm{pH}$ of the final solution was determined with a glass electrode $\mathrm{pH}$ meter from Corning Scientific Instruments (model 10) and all specimens were found to have the expected $\mathrm{pH}$.

\section{BILIRUBIN IN NITROGEN GAS-ENRICHED BUFFER}

Nitrogen gas-enriched bilirubin-buffer solutions of $\mathrm{pH} 7.4$ were prepared by saturating the degased buffer solutions with bubbled nitrogen gas (Matheson) and mixing bilirubin under a nitrogen atmosphere.

\section{BILIRUBIN IN SERA OR HUMAN SERUM ALBUMIN SOLUTIONS}

Bilirubin in human serum albumin (HSA) (Sigma) solution was prepared by first preparing $4 \mathrm{~g}$ crystalline albumin in $100 \mathrm{ml} 0.1 \mathrm{M}$ phosphate buffer, pH 7.4, and then adding bilirubin in $0.1 \mathrm{~N}$ $\mathrm{NaOH}$ to the HSA solution with appropriate addition of $0.1 \mathrm{~N}$ $\mathrm{HCl}$ to maintain the $\mathrm{pH}$ at 7.4. Naturally occurring unconjugated bilirubin in serum was obtained from human newborn infants with unconjugated hyperbilirubinemia and a patient with congenital nonhemolytic unconjugated hyperbilirubinemia, type I (1).

Bilirubin in HSA solution with increasing molar ratio of bilirubin to albumin (B:A) from 0.5 to 10 was prepared by mixing a

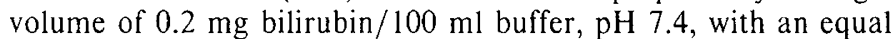
volume of HSA of varying concentrations $(11.8-236.0 \mathrm{mg} / 100 \mathrm{ml}$ buffer, $\mathrm{pH}$ 7.4) to yield the desired molar ratios. Bilirubin in human cord sera or human adult sera were prepared similarly by diluting sera with buffer such that the equivalent molar amount of native albumin was added to the bilirubin-buffer solution to maintain a fixed bilirubin concentration of $0.1 \mathrm{mg} / 100 \mathrm{ml}$. Calculations were based on an assumed molecular weight for HSA of 69,000 . Serum albumin concentrations were determined by the measurement of total protein (18) and percentage of albumin by agarose gel $(2 \%)$ electrophoresis in a Spectrophor I (Bausch and Lomb, Inc.) in $0.01 \mathrm{M}$ phosphate buffer, $\mathrm{pH} 8.5$, with $300 \mathrm{~V}$ applied for $90 \mathrm{~min}$. Densitometric readings of protein fractions were carried out at $205 \mathrm{~nm}$ through the quartz-plate bed and with electronic integration. Total and direct-reacting bilirubin in sera were determined by the method of Jendrassik and Grof (16).

\section{METHOD OF PRESENTATION OF SPECTRAL DATA}

Spectral curves $(380-600 \mathrm{~nm})$ are presented both as recorded and as normalized data. Normalization of curves was achieved by plotting the maximal optical density (OD) value for each curve as 1.0 on the ordinate and expressing all other points on the curve in their corrected relation to the maximum value. The normalization calculation was performed by dividing the $O D$ value at each wave length by the maximum $O D$ value for that curve and expressing each point on the curve other than the maximum as a fractional equivalent of unity in decimal equivalents. This permits comparison of OD values between different curves at each wave length.

\section{RESULTS}

\section{BILIRUBIN IN PHOSPHATE BUFFER}

Immediate spectral scanning of aqueous bilirubin, $0.5 \mathrm{mg} / 100$ $\mathrm{ml}$ buffer, $\mathrm{pH} 7.4$, gave a $440 \mathrm{~nm}$ maximal absorption and an $\mathrm{E}_{440^{\circ}}^{\mathrm{MM}}{ }^{\mathrm{Icm}}$, of $4.72 \times 10^{4} \pm 0.15(\mathrm{SE})(n=4)$ (Fig. 1). After the 
preparation stood for $10 \mathrm{~min}$, was shaken vigorously 10 times, or was stirred for $5 \mathrm{~min}$, the maximal absorption shifted from $440 \mathrm{~nm}$ to shorter wave lengths, the absorption at $440 \mathrm{~nm}$ decreased and a shoulder formed between 480 and $560 \mathrm{~nm}$, maximal between 490 and $500 \mathrm{~nm}$ (Fig. 1). Coincident with the formation of the $480-560$ $\mathrm{nm}$ shoulder, the bilirubin-buffer solution, which had previously appeared entirely clear, became visibly cloudy. The longer the agitation or standing, the greater the degree of shift and formation of shoulder.

On immediate spectral scanning, bilirubin in aqueous media, 0.5 $\mathrm{mg} / 100 \mathrm{ml}$ buffer at all $\mathrm{pH}$ values from 4 to 12 , demonstrated maximal spectral absorption at $440 \mathrm{~nm}$. At all $\mathrm{pH}$ values below 12, the maximal absorption OD was lower and the shoulder formation was wider and higher even before agitation or standing. This was

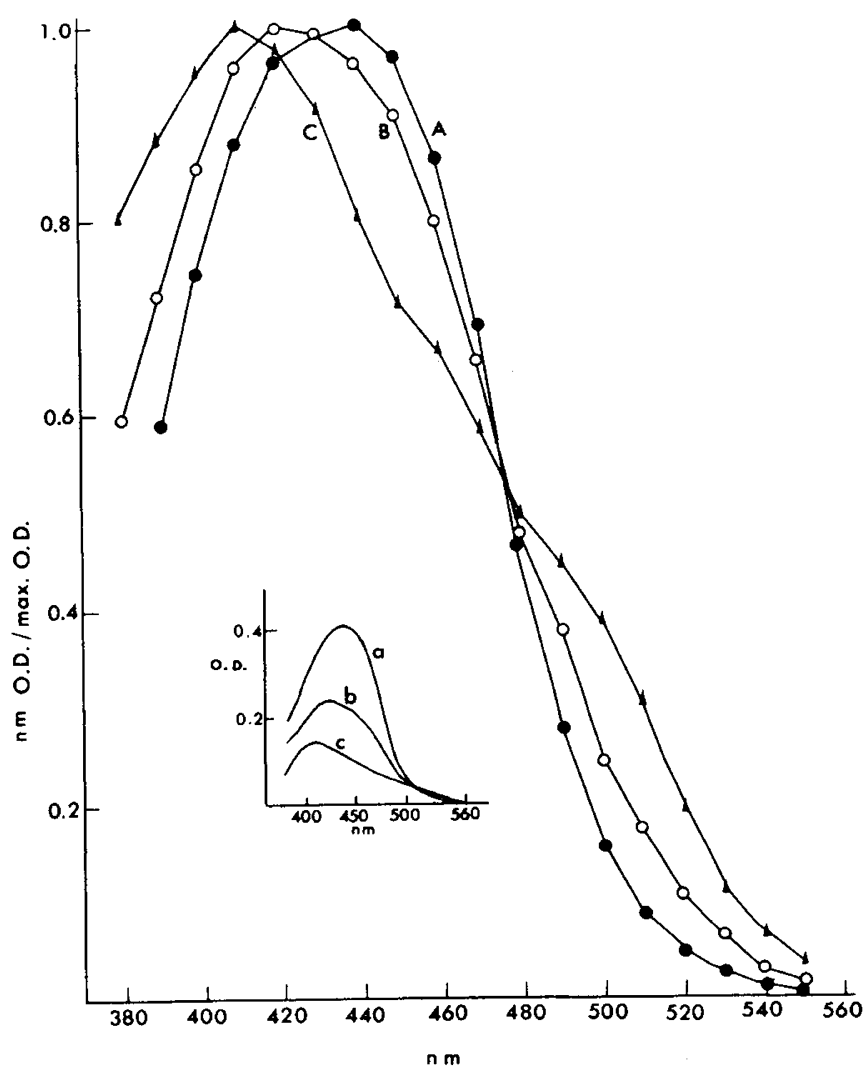

Fig. 1. Spectral absorption curves of bilirubin, $0.5 \mathrm{mg} / 100 \mathrm{ml}, 0.1 \mathrm{M}$ phosphate buffer, $\mathrm{pH}$ 7.4. $a$ : immediate reading; $b$ : reading after stirring for $15 \mathrm{~min} ; c$ : reading after $30 \mathrm{~min} . A, B$, and $C$ are normalized spectral curves for $a, b$ and $c$, respectively. most striking at $\mathrm{pH}$ values below 8 . After stirring aqueous bilirubin solutions at $\mathrm{pH} 12$ for $15 \mathrm{~min}$, there was a reduction and shift of maximal absorption to shorter wave lengths (420 and 415 $\mathrm{nm}$ ) but without any shoulder formation at $480-560 \mathrm{~nm}$ (Fig. 2). In contrast, at $\mathrm{pH} 6.0$ after stirring for $15 \mathrm{~min}$, there was a shift in the absorption peak to a longer wave length, $445 \mathrm{~nm}$, and formation of wider and higher shoulder at $480-560 \mathrm{~nm}$ than was the case with the similar treatment of the same solution at $\mathrm{pH} 7.4$ (Fig. 2).

After either mechanical agitation or exposure to light of aqueous bilirubin, the initial maximum OD (at $440 \mathrm{~nm}$ ) of bilirubin decreased progressively and to a greater degree at the lower concentration (Tables 1 and 2). At the higher bilirubin concentration, mechanical agitation brought an increase in spectral shoulder formation at $500 \mathrm{~nm}$ (Table 1). At the lower concentration, the exposure of aqueous bilirubin to light without mechanical agitation demonstrated an increase in OD at $420 \mathrm{~nm}$ (Table 2).

AQUEOUS BILIRUBIN WITH L-ASCORBIC ACID AND EDTA

Aqueous bilirubin, $0.5 \mathrm{mg} / 100 \mathrm{ml}$ buffer with L-ascorbic acid and EDTA at pH 7.4, demonstrated a maximal spectral absorp-

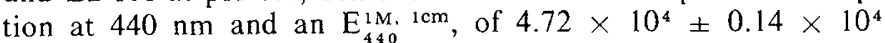
(SE) $(n=4)$, identical with that of aqueous bilirubin without L-ascorbic acid and EDTA (Figs. 1 and 3). After 30 min of stirring or shaking of the above bilirubin-buffer solution, progressive shoulder formation $(480-560 \mathrm{~nm}$ ) was noted but without any shift of the peak to the shorter wave lengths (Fig. 3). In contrast, at pH 12 , after stirring for $60 \mathrm{~min}$, bilirubin-buffer solution containing

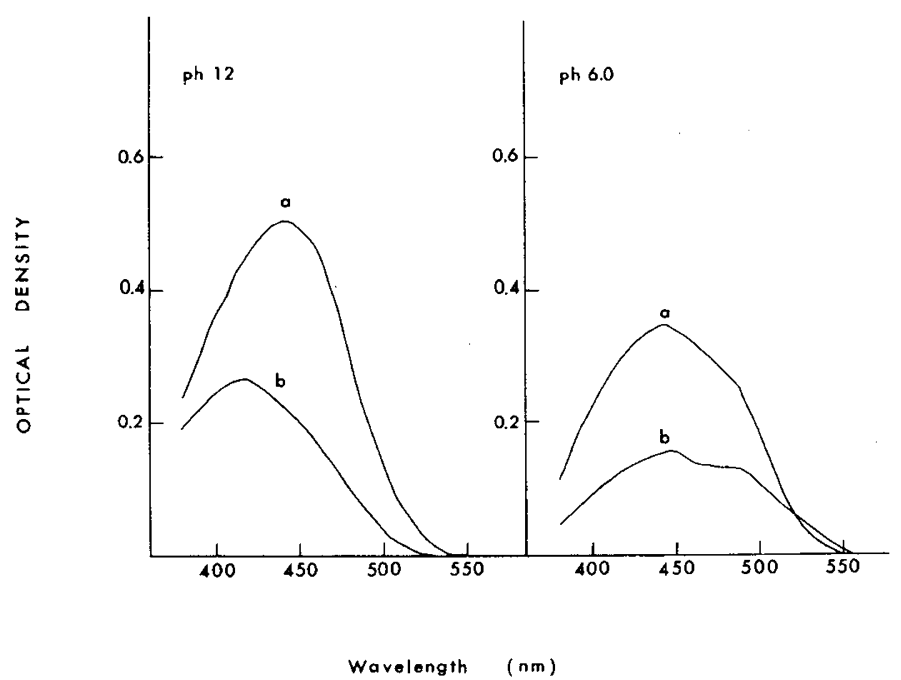

Fig. 2. Spectral absorption curves of billirubin, $0.5 \mathrm{mg} / 100 \mathrm{ml}, 0.1 \mathrm{M}$ phosphate buffer at $\mathrm{pH} 12$ and 6 . $a$ : immediate reading; $b$ : reading after stirring for $15 \mathrm{~min}$.

Table 1. Effect of mechanical agitation ${ }^{1}$ on spectral absorption of bilirubin in 0.1 M phosphate buffer, pH $7.4^{1}$

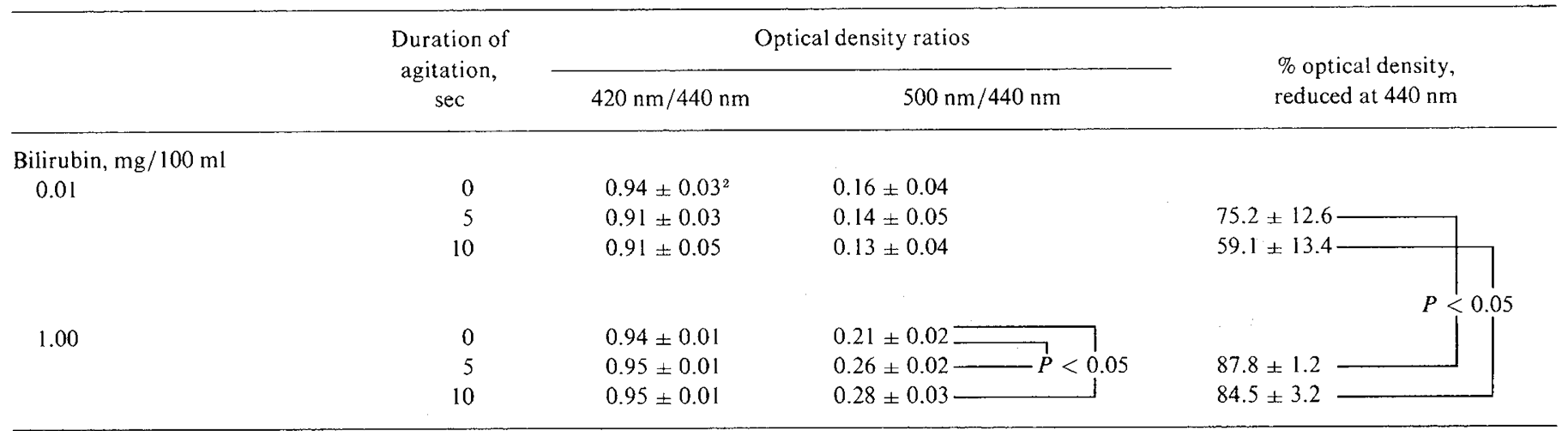

${ }^{1}$ Low mode, vortex test tube mixer, Scientific Industries, Inc.

${ }^{2}$ Mean $\pm \mathrm{SD}, n=4$ for each. 
BILIRUBIN: SPECTROPHOTOMETRIC CHARACTERISTICS

Table 2. Effect of light exposure ${ }^{1}$ on spectral absorption of bilirubin in $0.1 \mathrm{M}$ phosphate buffer, pH 7.4

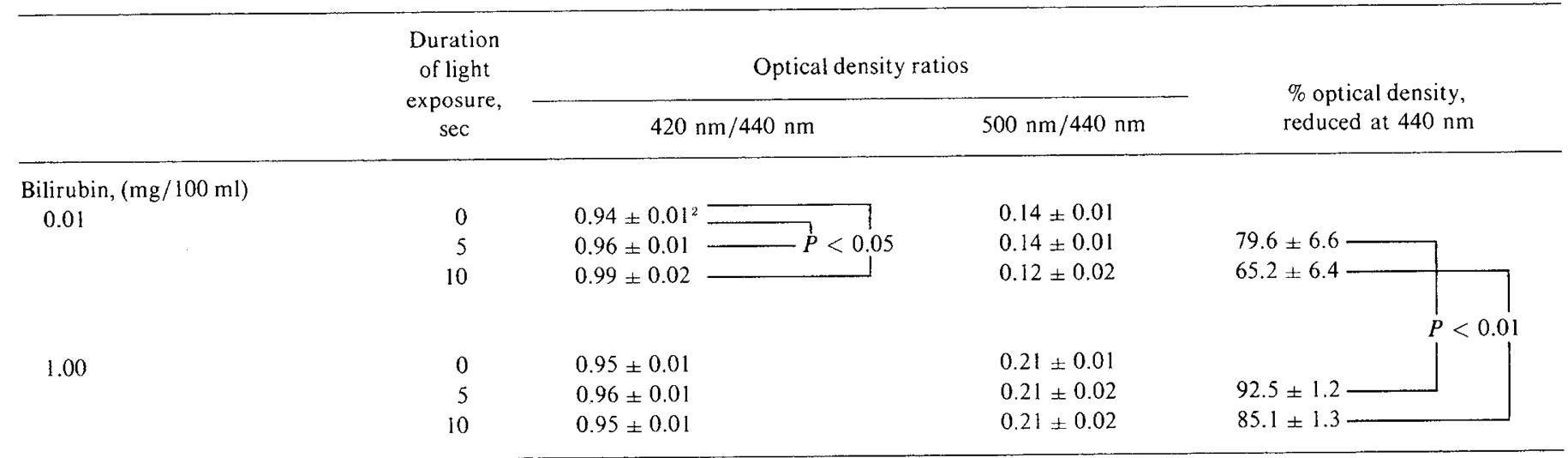

${ }^{1}$ Exposure distance: $45 \mathrm{~cm}$ from the light source which was eight 20 -W daylight fluorescent lamps (Westinghouse) housed in phototherapy unit, model no. PT-53-1. Air-Shields, Inc.

${ }^{2}$ Mean $\pm \mathrm{SD}, n=4$ for each.

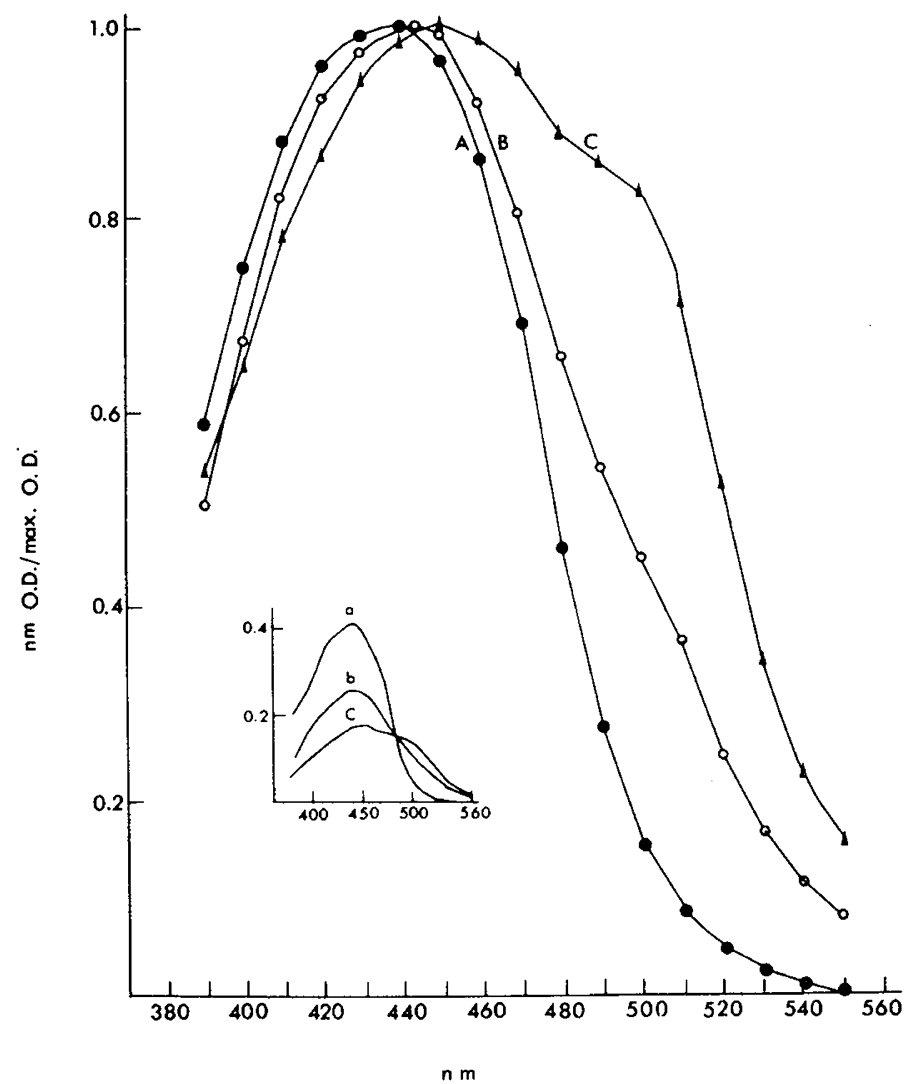

Fig. 3. Spectral absorption curves of billirubin, $0.5 \mathrm{mg} / 100 \mathrm{ml}, 0.1 \mathrm{M}$ phosphate buffer containing $5 \mathrm{mM} \mathrm{L-ascorbic} \mathrm{acid} \mathrm{and} 2 \mathrm{mM}$ EDTA at $\mathrm{pH}$ 7.4. $a$ : immediate reading; $b$ : reading after 30 min of stirring; $c$ : after stirring for $60 \mathrm{~min} . A, B$, and $C$ are normalized spectral curves for $a, b$, and $c$, respectively.

L-ascorbic acid and EDTA exhibited neither a shift of the spectral peak nor any shoulder formation.

In the presence of L-ascorbic acid and EDTA, bilirubin, 0.05 $\mathrm{mg} / 100 \mathrm{ml}$ buffer, at $\mathrm{pH}$ ranging from 4 to 12 , demonstrated less shift to the shorter wave lengths at each $\mathrm{pH}$ than that of aqueous bilirubin without L-ascorbic acid and EDTA. At this low bilirubin concentration $(0.05 \mathrm{mg} / 100 \mathrm{ml})$, the $E_{440}^{1 \mathrm{M} .1 \mathrm{~cm}}$ of bilirubin in creased progressively with each increase in $\mathrm{pH}$ up to $\mathrm{pH} 12$ and decreased with each decrease in $\mathrm{pH}$ down to 4.0 (Fig. 4). The greatest percentage of increase in $\mathrm{E}_{440}^{1 \mathrm{M}}, 1 \mathrm{~cm}$ was observed at $\mathrm{pH}$ between 7 and 8 (Fig. 4). The $\mathrm{E}_{440}^{1 \mathrm{M}}$. $1 \mathrm{~cm}$ at pH 12 was $6.35 \times 10^{4} \pm$

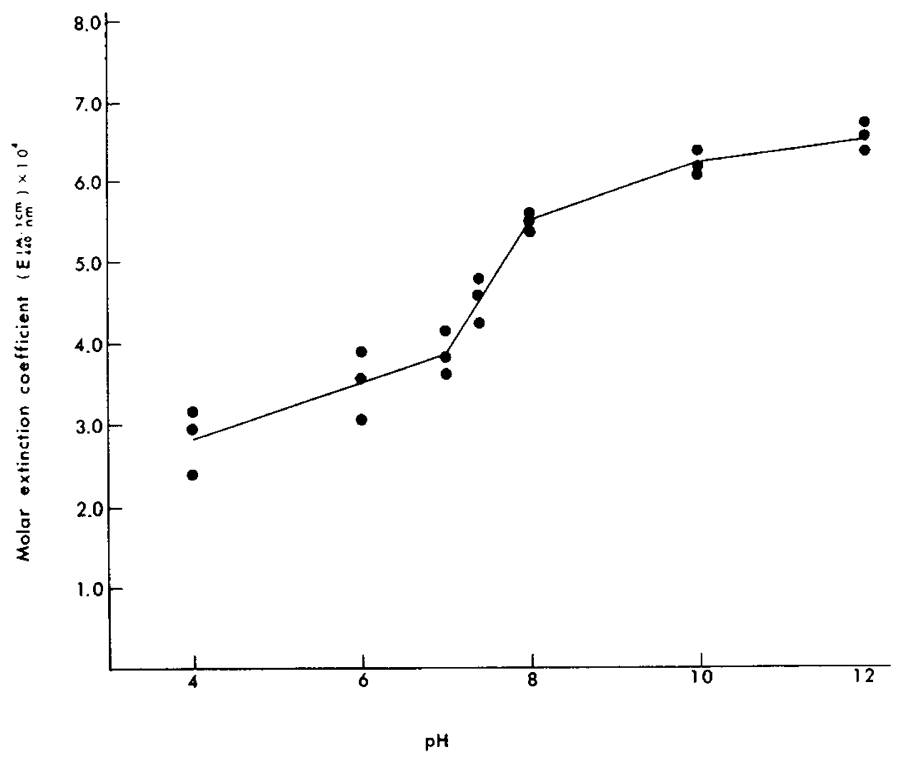

Fig. 4. Molar extinction coefficients of bilirubin in $0.1 \mathrm{M}$ phosphate buffer $(0.05 \mathrm{mg} / 100 \mathrm{ml})$ at $\mathrm{pH} 4-12$.

$0.21 \times 10^{4}(\mathrm{SE})(n=3)$, a value $6.5 \%$ greater than the $\mathrm{E}_{453}^{1 \mathrm{M}} \cdot 1 \mathrm{~cm}$ of the same bilirubin in chloroform. Over a range of bilirubin concentrations from 0.005 to $2.500 \mathrm{mg} / 100 \mathrm{ml}$ buffer, $\mathrm{pH} 7.4$, the $\mathrm{E}_{440}^{1 \mathrm{M}, 1 \mathrm{~cm}}$ did not change significantly and the mean was $4.61 \times$ $10^{4} \pm 0.13 \times 10^{4}(\mathrm{SE})(n=40)$.

\section{BILIRUBIN IN NITROGEN GAS-ENRICHED BUFFER}

Bilirubin, $0.5 \mathrm{mg} / 100 \mathrm{ml}$, prepared in degassed, nitrogen gas-enriched buffer at $\mathrm{pH} 7.4$, had spectral characteristics identical with those of aqueous bilirubin with L-ascorbic acid and EDTA, indicating that the addition of antioxidant chemicals had no effect on spectral characteristics, other than inhibition of oxidation. No shift of maximal absorption peak was observed even after $30 \mathrm{~min}$ of stirring, but progressive shoulder formation $(480-560 \mathrm{~nm}) \mathrm{did}$ occur, as in the L-ascorbic acid-EDTA experiment at $\mathrm{pH} 7.4$.

\section{BILIRUBIN IN SERA OR HUMAN SERUM ALBUMIN SOLUTIONS}

Bilirubin in HSA solution (bilirubin $0.5 \mathrm{mg} / 100 \mathrm{ml}$; B:A molar ration $=1$ ) at $\mathrm{pH} 7.4$ gave a maximal absorption at $460 \mathrm{~nm}$ with $\mathrm{E}_{460}^{1 \mathrm{M}}{ }^{1 \mathrm{~cm}}$ of $4.70 \times 10^{4} \pm 0.13 \times 10^{4}(\mathrm{SE})(n=4)$. Human adult sera with added unconjugated bilirubin, sera from patients with congenital nonhemolytic unconjugated hyperbilirubinemia, type I 
(1), and neonatal physiologic hyperbilirubinemia demonstrated the same spectral absorption peak at $460 \mathrm{~nm}$.

In the presence of reduced concentrations of HSA (bilirubin 0.5 $\mathrm{mg} / 100 \mathrm{ml}$; B:A molar ratios $=5$ and 10 ), a shift of maximal absorption peaks to the shorter wave lengths was observed with immediate scanning, approaching that of aqueous bilirubin (Fig. 5). After stirring for $60 \mathrm{~min}$, there was a progressive reduction in maximal absorption with shoulder formation at $480-560 \mathrm{~nm}$ but the spectral changes were less pronounced than those of aqueous bilirubin (Fig. 6).

\section{DISCUSSION}

The study defines the spectral characteristics of bilirubin undergoing various changes of physical state and demonstrates the influence of the interactions of these variables on spectral absorptions of bilirubin.

With great care taken in the preparation of aqueous bilirubin solutions, so that oxidation and excessive agitation are avoided, the wave length of the maximal absorption is $440 \mathrm{~nm}$ and $E_{440}^{1 \mathrm{M}} \mathrm{icm}$ of this material is $4.67 \times 10^{4}$ at $\mathrm{pH} 7.4$. With exposure to air over a period of 5-30 min, a progressive reduction and shift of the maximal absorption to the shorter wave lengths occur. These spectral alterations could be prevented by addition of antioxidants to the buffer or by removing oxygen from the buffer. Thus, these spectral alterations appear to be due to oxidation of bilirubin, as has been shown by others $(8,20,27,28)$. These alterations were progressively more accentuated by a progressive decrease in bilirubin concentration and/or an increase in $\mathrm{pH}$ positively associated with the proportion of bilirubin solubilized in the buffer.

The other observed spectral alterations were reduction and shift of the maximal absorption to the longer wave lengths with concomitant shoulder formation between 480 and $560 \mathrm{~nm}$. These

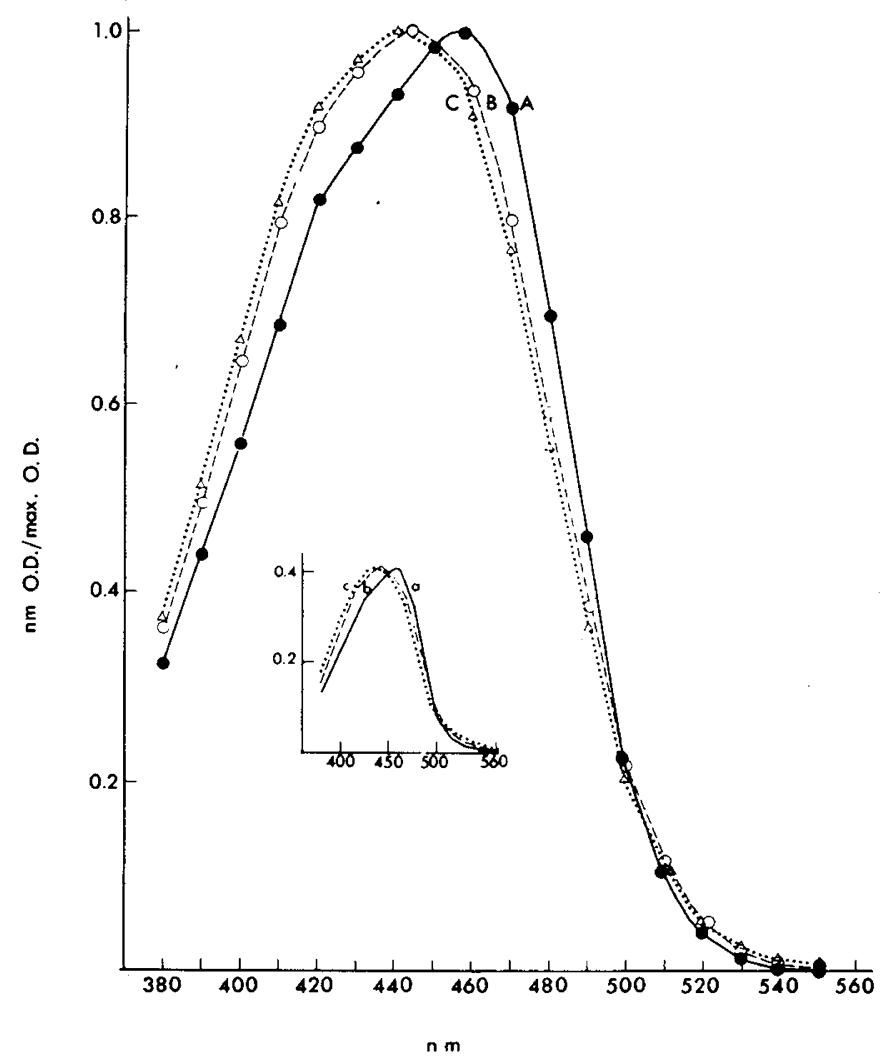

Fig. 5. Spectral absorption curves of bilirubin (immediate reading), 0.5 $\mathrm{mg} / 100 \mathrm{ml}, 0.1 \mathrm{M}$ phosphate buffer, $\mathrm{pH} 7.4$, containing human serum albumin. $a$ : at a bilirubin to albumin molar ratio of $0.5, b$ : ratio of $5.0 ; c$ : ratio of 10.0. $A, B$, and $C$ are normalized spectral curves for $a, b$, and $c$, respectively.

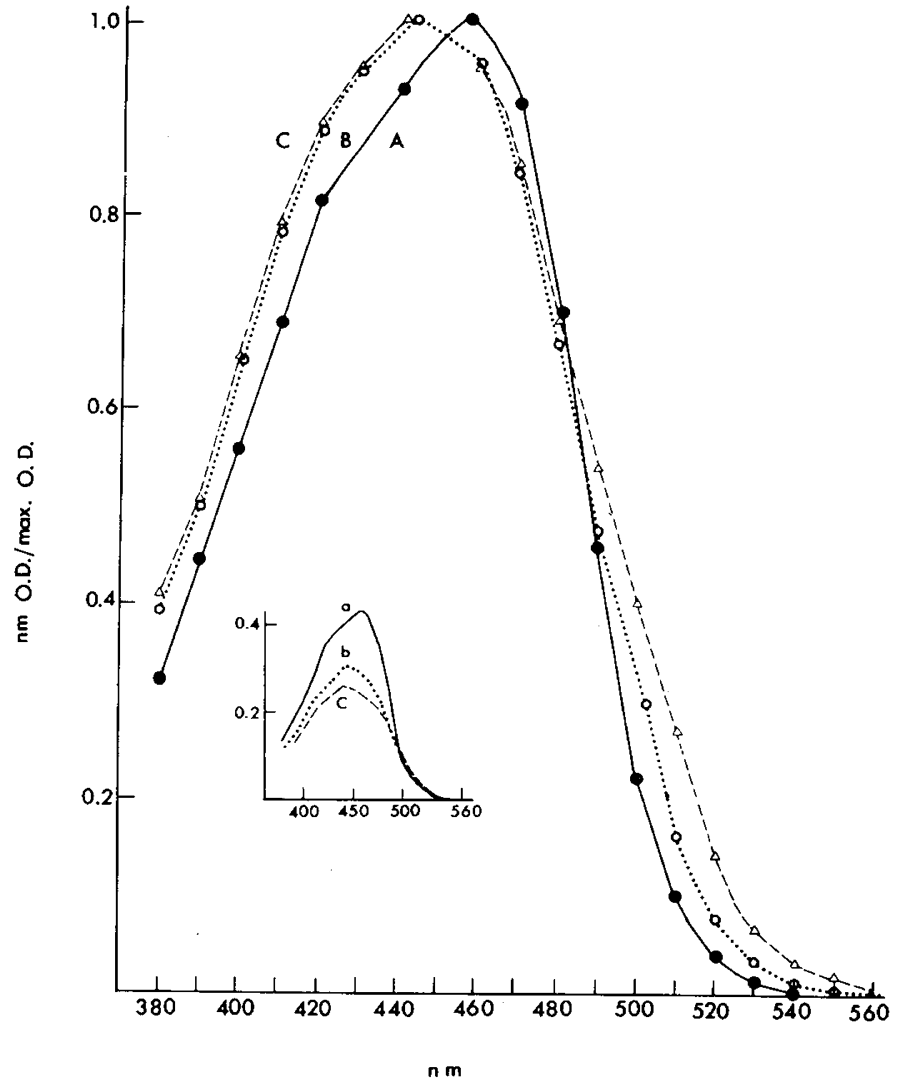

Fig. 6. Spectral absorption curves of bilirubin, $0.5 \mathrm{mg} / 100 \mathrm{ml}, 0.1 \mathrm{M}$ phosphate buffer, $\mathrm{pH} 7.4$, containing human serum albumin after stirring for 1 hr. $a$ : at a bilirubin to albumin molar ratio of $0.5 ; b$ : ratio of $5.0 ; c$ : ratio of 10.0. $A, B$, and $C$ are normalized spectral curves for $a, b$, and $c$, respectively.

spectral alterations coincided with the development of turbidity and bilirubin-staining of the wall of a cuvette or a beaker. This finding is similar to Brodersen and Theilgaard's observation (6) of $490 \mathrm{~nm}$ shoulder formation by bilirubin aggregates. These spectral characteristics, in contrast with those due to oxidation, were progressively accentuated as the concentration of bilirubin increased and/or the $\mathrm{pH}$ was lowered. Increase in $\mathrm{pH}$ in the alkaline range progressively reduced spectral shoulder formation. As suggested by Brodersen (3), bilirubin appears to exist as a colloidal material whenever its very limited aqueous solubility is exceeded.

Thus, bilirubin in aqueous media at the concentrations used in this study would exist in several states with some molecules truly in solution, whereas the great majority are in a finely dispersed colloidal state (colloidal sol). As a finely dispersed colloid, they could enter into solution resulting in an increasing molar extinction coefficient, as demonstrated with increasing $\mathrm{pH}$ of the media. Increased solubility of bilirubin in alkaline $\mathrm{pH}$ has been suggested to be due to its decreased ability to form hydrogen bonding of propionic acid side chains, intramolecularly or between molecules, and removal of hydrogen ions from these side chains (4). With agitation of the bilirubin preparation at $\mathrm{pH} 7.4$, the generated kinetic energy would be expected to overcome the repulsion between finely dispersed colloidal micropolymers of bilirubin and form larger aggregates (flocculants) producing the $480-560 \mathrm{~nm}$ spectral shoulder. When these flocculants achieve sufficient size they would then precipitate. This observation fits well with modern concepts of the behavior of hydrophobic colloids (36).

If, in the preparation of bilirubin solutions, excessive agitation and exposure to light or oxygen takes place, new physical or chemical states of the pigment will develop. Many of these changes produce new spectral characteristics, the final appearance of which may represent a composite of the characteristics of four possible 
types of pigment: (l) bilirubin truly in solution with a $440 \mathrm{~nm}$ maximal absorption; (2) finely dispersed bilirubin colloid, with spectral characteristics indistinguishable from those of soluble bilirubin; (3) bilirubin flocculant with maximal absorption between 480 and $560 \mathrm{~nm}$; and (4) oxidation products of bilirubin with shorter wave lengths of maximal absorption. The proportion of each type of pigment in a preparation depends on concentration, $\mathrm{pH}$, time, degree of mechanical agitation, and presence of oxidants, including molecular oxygen and trace metals. These types of changes probably account for the widely varying reports as to the wave length of maximal absorption, ranging from 420 to $440 \mathrm{~nm}$, as well as the variously reported molar extinction coefficients for bilirubin in aqueous media $(10,19,37,38)$.

The solubility of bilirubin in aqueous solution as reported in the literature also varies widely $(6,7,19,29)$. Utilizing a dialysis method, Martin (19) reported that $0.1 \mathrm{mg} / 100 \mathrm{ml}$ bilirubin was soluble in $0.1 \mathrm{M}$ phosphate buffer at $\mathrm{pH}$ 7.4. Burnstine and Schmid (7) gave the solubility of bilirubin as approximately $7 \mathrm{mg} / 100 \mathrm{ml}$ by an ultracentrifugation method and Brodersen and Theilgaard (6) reported $0.1 \mu \mathrm{M}(0.0058 \mathrm{mg} / 100 \mathrm{ml})$ by the evidence of colloid formation at the same ionic strength and $\mathrm{pH}$. By potentiometric titration, Overbeek et al. (29) estimated that less than 0.003 $\mu \mathrm{g} / 100 \mathrm{ml}$ was soluble in solutions with ionic strengths ranging from 0.003 to 0.006

We anticipate that the molar extinction coefficient would decline with increasing bilirubin concentration if solubility were exceeded at some specific concentration. However, at bilirubin concentrations ranging from 0.005 to $2.500 \mathrm{mg} / 100 \mathrm{ml}$, no statistically significant change in molar extinction coefficient was observed. With increasing concentrations of bilirubin, there appears to be an increase in the amount of bilirubin in "colloidal sol." In contrast, significantly higher extinction coefficient $\left(\mathrm{E}_{440}^{\mathrm{MM}}, \mathrm{cm}\right)$ was obtained by increasing the $\mathrm{pH}$, suggesting that increasing solubility is associated with increasing light absorptivity of the pigment. At pH 7.4 , decreasing the concentration of bilirubin to the lowest concentration detectable with present equipment did not result in a significant increase in the molar extinction coefficient, suggesting that even at $0.005 \mathrm{mg} / 100 \mathrm{ml}$, the majority of the pigment was not in true solution. Moreover, shoulder formation was observed, indicating that the true solubility of bilirubin in $0.1 \mathrm{M}$ phosphate buffer at $\mathrm{pH} 7.4$ must be lower than $0.005 \mathrm{mg} / 100 \mathrm{ml}$.

Bilirubin in HSA solution $(\mathrm{B}: \mathrm{A}=1)$ at $\mathrm{pH} 7.4$ gave a spectral peak at $460 \mathrm{~nm}$ with $\mathrm{E}_{460}^{1 \mathrm{M} .}{ }_{1 \mathrm{~cm}}$ of $4.70 \times 10^{4}$, not different from that of aqueous bilirubin at the same $\mathrm{pH}$, suggesting that albumin may stabilize finely dispersed bilirubin colloid although not increasing the solubility of bilirubin.

This study has implications for both laboratory and clinical studies of bilirubin. Most investigators $(6,20,27,29)$ recognize the instability of bilirubin preparations and guard against exposure to light and heat in order to minimize oxidation. The importance of duration and degree of agitation in the preparation of bilirubin in aqueous media has not been recognized, however. In studies of bilirubin binding and of spectral characteristics this may be of enormous importance. Details of procedures used in preparation of bilirubin solutions should be described. Prolonged stirring of concentrated bilirubin preparation before its addition to albumin for studies of albumin binding will seriously alter the subsequent binding determinations. Failure to adhere to strict routines will result in poor reproducibility.

It has been suggested that the transfer of unbound unconjugated bilirubin into the central nervous system is responsible for kernicterus $(9,24,26)$. The nature and amount of unbound bilirubin in whole blood should therefore be a critical factor in the development of kernicterus. Various investigators have estimated unbound bilirubin concentrations in newborn infant sera at from 0.05 to $3.00 \mathrm{mg} / 100 \mathrm{ml}(15,34,40)$. These concentrations of unbound bilirubin in sera exceed the true solubility of bilirubin and, therefore, most of the bilirubin would be expected to exist as colloid bilirubin. Brodersen (3) postulated that colloidal bilirubin may cocrystallize with albumin to form macroaggregates (floccu- lants) and thus prevent the transfer of bilirubin to the central nervous system. This may be true for bilirubin flocculant, but may not be so for finely dispersed bilirubin colloid.

At the present time, two alternative speculations for bilirubin transport to the central nervous system can be formulated on the basis of this study and others $(9,24,26)$. The first speculation is that although the concentration of solubilized bilirubin in plasma water may be extremely small, a large amount of truly soluble bilirubin may be able to enter the brain as a result of a rapid rate of equilibration between colloidal and solubilized forms. The secondpostulate would be that unbound bilirubin in serum at the concentrations exceeding albumin binding capacity and its aqueous solubility must exist either as a colloidal sol or a flocculant; therefore, finely dispersed bilirubin colloid may enter cell membranes, where, either in colloidal state or after solubilization in cellular membrane lipids, it may be transported to subcellular organelles (mitochondria) where its toxic effect on cellular metabolism may result in impaired cellular function or cell death.

Bilirubin impairs the function of erythrocyte (30) and brain mitochondria $(22,31)$. Congenitally hyperbilirubinemic Gunn rats manifest impaired renal function (25) as well as decreased protein synthesis in the brain compared with nonicteric, heterozygote Gunn rats (12). The reported spectral curves of bilirubin associated with red cell membrane (17), phospholipid fraction of mitochondria (23), and unesterified fatty acids (11) are identical with that of bilirubin flocculant described in this communication.

Further delineation of states of bilirubin in vivo and in vitro may expand our understanding of the pathophysiology of bilirubin toxicity to various organs, including the brain.

\section{SUMMARY}

Spectrophotometric characteristics of bilirubin have been studied under various physical conditions. Mechanical agitation of bilirubin preparation at $\mathrm{pH} 7.4$ progressively reduced and altered the maximal spectral absorption $(440 \mathrm{~nm})$ of bilirubin in aqueous media. The reduction of maximal absorption and its shift to the shorter wave lengths are attributed to oxidation of bilirubin, whereas the reduction and spectral shoulder formation at 480-560 $\mathrm{nm}$ are attributed to the formation of large size bilirubin flocculate. The formation of flocculants when a "solution" is agitated indicates that significant portions of the pigment were, in fact, not in solution and must have existed previously as a finely dispersed colloidal sol or supersaturated solution which progressed to a colloidal sol.

Spectral curves of bilirubin may represent a composite resulting from four physical states of bilirubin: (l) bilirubin truly in solution; (2) bilirubin in fine colloidal dispersion; (3) bilirubin flocculant; and (4) oxidation products of bilirubin.

Bilirubin in colloid form may exist in vivo and be responsible for bilirubin toxicity to various tissues.

\section{REFERENCES AND NOTES}

I. Arias, I. M., Gartner, L. M., Cohen, M. I., Ben Ezzer, J., and Levi, J.: Chronic nonhemolytic unconjugated hyperbilirubinemia with hepatic glucuronyl transferase deficiency: Clinical, biochemical, pharmacologic evidence for heterogeneity. Amer. J. Med., 47: 395 (1969).

2. Bourrillon, R.: Analyse spectrophotometrique de la bilirubine plasmatique. Bull. Soc. Chim. Biol. (Paris). 40: 111 (1958).

3. Brodersen, R.: Supersaturation with bilirubin followed by colloid formation and disposition. With a hypothesis on the etiology of kernicterus. Scand. J. Clin. Lab. Invest., 29: 447 (1972).

4. Brodersen, R., Flodgaard, H., and Krogh Hansen, J.: Intramolecular bonding in bilirubin. Acta Chem. Scand., 21: 2284 (1967).

5. Brodersen, R., Funding, L., Pedersen, A. O., and Roigaard-Petersen, H.: Binding of bilirubin to low-affinity sites of human serum albumin in vitro followed by co-crystallization. Scand. J. Clin. Lab. Invest., 29: 433 (1972).

6. Brodersen, R., and Theilgaard, J.: Bilirubin colloid formation in neutral aqueous solution. Scand. J. Clin. Lab. Invest., 24: 395 (1969).

7. Burnstine, R. C., and Schmid, R.: Solubility of bilirubin in aqueous solution. Proc. Soc. Exper. Biol. Med., 109: 356 (1962).

8. Cremer, R. J., Perryman, P. W., and Richards, D. H.: Influence of light on the hyperbilirubinemia of infants, Lancet, $i: 1094$ (1958).

9. Diamond, I., and Schmid, R.: Experimental bilirubin encephalopathy: The mode 
of entry of bilirubin- ' $\mathrm{C}$ into the central nervous system. J. Clin. Invest., 45: 678 (1966).

10. Fog, J., and Bakken, A. F.: Absorptivity of alkaline bilirubin and bilirubin in serum. Scand. J. Clin. Lab. Invest., 20: 70 (1967).

11. Gartner, L. M., and Lee, K. S.: Bilirubin transport, free fatty acids and a new concept for the pathogenesis of kernicterus. Presented at the International Symposium on Bilirubin Metabolism in the Newborn, Jerusalem, Israel. April 1974. (In press.)

12. Greenfield, S. S., and Majumdar, A. P. N.: Bilirubin encephalopathy: Effect on protein synthesis in the brain of the Gunn rat. J. Neurol. Sci., 22: 83 (1974).

13. Herz, H., and Dybkaer, R.: Molar absorption coefficients for bilirubin in adult and infant serum with determination of an isosbestic point. Scand. J. Clin. Lab. Invest., 29: 217 (1972).

14. Jackson. S. H., and Hernandez. A. H.: A new "bilirubinometer" and its use in estimating total and conjugated bilirubin in serum. Clin. Chem., 16:462 (1970).

15. Jacobsen, J., and Fedders, O.: Determination of non-albumin-bound-bilirubin in human serum. Scand. J. Clin. Lab. Invest., 26: 237 (1970).

16. Jendrassik, L., and Grof, P.: Vereinfachte photometrische Methoden zur Bestimmung des Blut-Bilirubins. Biochem. Z., 297: 81 (1939).

17. Kapoor, C. L., Kishna Murti, C. R., and Bajpai, P. C.: Toxic effect of bilirubin on human red blood cell and its reversal with lipids. Indian J. Med. Res., 60: $918(1972)$.

18. Lowry, O, H., Rosebrough, N. J., Farr, A. L, and Randall, R. J: Protein measurement with the Folin phenol reagent. J. Biol. Chem., 193: 265 (1951).

19. Martin, N. H.: Preparation and properties of serum and plasma proteins. XXI Interactions with bilirubin. 1. Amer. Chem. Soc. 71: 1230 (1967)

20. McDonagh, A. F.: The role of singlet oxygen in bilirubin photooxidation. Biochem. Biophys. Res. Commun., 44: 1306 (1971).

21. Michaelsson, M.: Evaluation of method for determination of bilirubin in serum using direct spectrophotometry. Scand. J Clin. Lab. Invest. 30:387 (1972).

22. Mustafa, M. G., Cowger, M. L., and King, T. E.: The effect of bilirubin on mitochondrial reactions. J. Biol. Chem., 244: 6403 (1969).

23. Mustafa, M. G., and King, T. E.: Binding of bilirubin with lipids: A possible mechanism of its toxic reactions in mitochondria. J. Biol. Chem., 245: 1084 (1970).

24. Odell, G. B.: Studies in kernicterus. I. The protein binding of bilirubin. J. Clin. Invest., $3 \dot{8}: 823$ (1959)

25. Odell, G. B., Bolen, J. L., Poland, R. L., Seungdamrong, S., and Cukier, J. O. Protection from bilirubin nephropathy in jaundiced Gunn rats. Gastroenterology, 66: 1218 (1974)

26. Odell, G. B., Cohen, S. N., and Kelly, P. C.: Studies in kernicterus. II. The determination of the saturation of serum albumin with bilirubin. J. Pediat., 74 : 214 (1969).

27. Ostrow, J. D., and Branham, R. V.: Photodecomposition of bilirubin and

Copyright (C) 1976 International Pediatric Research Foundation, Inc. biliverdin in vitro. Gastroenterology, 58: $15(1970)$

28. Ostrow, J. Hammaker, L and Schmid. R. The preparation of crystalline bilirubin-C". J. Clin. Invest., 40:1442 (1962)

29. Overbeek, J. T. G., Vink, C. L. J., and Denstra, H.: The solubility of bilirubin. Rec. Trav. Chim. Pays-Bas, 74(4): 81 (1955).

30. Petrich, V., Gempp-Friedrich, W and Gobel, U. Comparative measurements of enzyme activities and 2,3-diphosphoglycerate in the erythrocytes of newborns with and without transitory hyperbilirubinemia. Acta Pediat. Stockh., 62: 596 (1973).

31. Rose, A. L., and Johnson, A. B.: Bilirubin encephalopathy: Neuropathological and histochemical studies in the Gunn rat model. Neurology, 22: 420 (1972).

32. Sioni, R., Sauwalder, H., and Richterich, R.: Ein vergleich physikalischer und chemischer Methoden zur Bestimmung des Plasmabilirubins. Schweiz. Med. Wschr. 99: 1784 (1969).

33. Shinowara, G. Y.: Spectrophotometric studies in blood serum and plasma. The physical determination of hemoglobin and bilirubin. Amer. J. Clin. Pathol., 24: 696 (1954).

34. Schiff, D. Chan, G. and Stern, L. Sephadex G-25 quantitative estimation of free bilirubin potential in jaundiced newborn infants` sera: A guide to the prevention of kernicterus. J. Lab. Clin. Med., 80: 445 (1972).

35. Standards Committee: A uniform bilirubin standard. Recommendations of the College of American Pathologists. Amer. J. Clin. Pathol.. 39: 90 (1963).

36. Vold, M. J., and Vold, R. D.: Colloid Chemistry, p. 9 (Van Nostrand Reinhold Co., New York, 1964)

37. Wennberg, R. P., and Cowger, M. L.: Spectral characteristics of bilirubin bovine albumin complexes. Clin. Chim. Acta, 43: 55 (1973).

38. With, T. K.: Spectral absorption of bilirubin. Measurements in pure aqueous solution and in solutions containing human sera. Acta Physiol. Scand., 10: 172 (1945).

39. Woolley, P. V., III, and Hunter, M. J. Binding and circular dichroism data on bilirubin-albumin in the presence of oleate and salicylate. Arch. Biochem. Biophys., 140: 197 (1970).

40. Zamet, P., and Chunga, F.: Separation by gel filtration and microdetermination of unbound bilirubin. II Study of sera in icteric newborn infants. Acta Pediat. Scand. 60: 33 (1971).

41. Dr. Gartner is a Career Development Awardee from the National Institute for Child Health and Human Development.

42. This work has been supported by grants from the National Institute for Child Health and Human Development NIH 5 R01-HD 03783 and the Gail I. Zuckerman Foundation for Research in Chronic Liver Diseases in Children.

43. Requests for reprints should be addressed to: L. M. Gartner, M.D., Department of Pediatrics, Albert Einstein College of Medicine, 1300 Morris Park Ave., Bronx, N.Y. 10461 (USA).

44. Accepted for publication March 15, 1976

Pediat. Res. 10: 788-791 (1976)

Bilirubin

hyperbilirubinemia $\mathrm{Rh}$ erythroblastosis liver

\title{
The Effect of Promethazine Hydrochloride on Bilirubin Metabolism in the Rat
}

\author{
SERGIO L. VAISMAN, KWANG-SUN LEE, AND LAWRENCE M. GARTNER ${ }^{(22)}$ \\ Division of Neonatology, Department of Pediatrics, The Rose F. Kenned. Center for Research in Mental Retardation \\ and Human Development and the Liver Research Center, Albert Einstein College of Medicine, \\ Bronx, New York, USA
}

\section{Extract}

The effect of 21 days of promethazine-HCl administration on hepatic bilirubin metabolism and transport was studied in adult rats. A significant increase in mean cumulative hepatic bilirubin uptake $(84.5 \pm 7.6(\mathrm{SE}) \mu \mathrm{g} / 100 \mathrm{~g} / \mathrm{min}$ in controls $v s$. $110.0 \pm 4.3 \mathrm{in}$ treated rats), mean hepatic glucuronide conjugation $(1,330 \pm 86$ (SE) $\mu \mathrm{g}$ bilirubin conjugated $/ \mathrm{g}$ liver $/ \mathbf{4 0} \mathrm{min}$ in controls $v s$. $1,713 \pm 61$ in treated rats), and mean maximal hepatic excretion $(47.2 \pm 4.9(\mathrm{SE}) \mu \mathrm{g} / 100 \mathrm{~g} / \mathrm{min} v s .63 .5 \pm 2.7)$ was observed in treated animals. Mean total liver weight and total hepatic protein also increased significantly.

These observations suggest that promethazine is an inducer of protein and enzyme synthesis in rat liver and is capable of significantly stimulating the three major steps in hepatic disposal of bilirubin.

\section{Speculation}

The stimulatory effect of promethazine on bilirubin metabolism and transport introduces a second or alternate explanation for the 